\title{
Output-Based Instruction, Learning Styles and Vocabulary Learning in the EFL Context of Iran
}

\author{
Behnaz Rastegar (Corresponding author) \\ Tehran Payame Noor University, Iran \\ E-mail: Rastegar.Beh@gmail.com \\ Fatemeh Safari \\ Allameh Mohaddes Nouri University, Nour, Iran \\ E-mail: f.hsafari2010@gmail.com
}

Received: 01-04-2017

doi:10.7575/aiac.ijels.v.5n.2p.101

Accepted: 29-04-2017

Published: 30-04-2017

URL: http://dx.doi.org/10.7575/aiac.ijels.v.5n.2p.101

\begin{abstract}
Language learners' productive role in teaching and learning processes has recently been the focus of attention. Therefore, this study aimed at investigating the effect of oral vs. written output-based instruction on English as a foreign language (EFL) learners' vocabulary learning with a focus on reflective vs. impulsive learning styles. To this end, 131 learners were chosen among 182 learners by taking Nelson vocabulary proficiency test. Next, the participants received a valid Persian version of reflective thinking (Kember et al., 2000) and Barratt, Patton and Stanford (1975) BIS (Barratt's Impulsiveness Scale) 11 impulsiveness questionnaires, based on which both experimental groups were divided into impulsive and reflective subgroups, but the control group consisted of both impulsive and reflective learners. After 15 sessions of intervention and based on the results through one-way ANOVA and independent t-test it was concluded that both oral output and written output had significant effect on vocabulary learning of reflective and impulsive EFL Learners. It was also observed that the effect of both oral output and written output on impulsive (oral group's mean=21.04; written groups' mean= 21.75) learners and reflective learners (oral groups' mean=22.38; written group's mean: 22.23) is not significantly different. Pedagogical implications are discussed.
\end{abstract}

Keywords: Impulsive learners, Reflective learners, Oral output-based instruction, Written output-based instruction, Vocabulary learning

\section{Introduction}

The role of vocabulary in learning processes in EFL/ESL settings is undeniable (Coady \& Huckin, 1997; Nation, 2001), so much so that Folse (2008) posited that EFL learners' comprehension of language depends on the vocabulary they acquire. He also noted that insufficient knowledge of vocabulary results in inauthentic communication. On the other hand, the intensive study of vocabulary has revealed that successful vocabulary learning requires learners' cooperation in the learning process (Kumaravadivelu, 2006). In the same vein, Winke and Abbuhl (2007) reposted that output-based vocabulary learning strategies are more effective than input-based ones. Such assumptions about vocabulary learning have resulted in a movement from input-based vocabulary learning which is mostly based on Krashen's theories in 1980 s to more output-based and student-centered approaches to learning vocabulary.

Moreover, focus has been accorded to the effect of learning styles on vocabulary learning of language learners (Laufer, 1998; Isazadeh, Makui, \& Ansarian, 2016). Indeed, learning styles, defined as one's preference in learning (Kolb \& Kolb, 2005), have been a query in research on vocabulary, though researchers have not reached a consensus regarding it. While some studies have reported no relationship between learning styles and vocabulary learning (e.g, Yeh \& Wang, 2003), some studies, e.g., Gu (2003), Oxford and Crookall (1989) have found the effective significant.

Given the context of Iran, the number of studies that have dealt with output-based vocabulary learning and the interactional effect of learning styles with vocabulary learning is scant. Among few studies that have investigated output-based vocabulary learning, e.g., Maftoon and Sharif Haratmeh (2013), different modes of output-based approaches, i.e., written and oral have not been investigated. As a result the effect of such recent approaches on vocabulary learning of Iranian EFL learners in still not understood comprehensively. In addition, institutional legislations in Iran require most language classes to be discriminated based on learners' gender, though other factors such as learning styles may also play a role in matching the learners in classes. This indicates the need for a study to find out whether or not discrimination based on learners' learning styles is necessary. Needless to mention ignorance toward such issues may result in inefficient vocabulary learning, whereas considering the factors that affect the process of vocabulary learning can aid the process. 
It should also be stated that the overall purpose of this study was to determine the effect of written vs. oral output-based instruction on vocabulary learning of impulsive vs. reflective learners so that both educators and language learners in the field could have a clearer picture of this effect and could make more effective decisions about how vocabulary should be taught or learnt. In addition, the prime significance of this study lies in its attempt in providing empirical evidence on the effect of two main types of output-based instruction, i.e., written vs. oral, and two of the cognitive learning styles, i.e., impulsivity and reflectivity on vocabulary learning of Iranian EFL learners.

\subsection{Hypotheses}

In order to pursue the purposes of this study, the following hypotheses were proposed:

H01: Oral output does not have any effect on vocabulary learning of Iranian reflective EFL learners.

H02: Written output does not have any effect on vocabulary learning of reflective Iranian EFL Learners.

H03: Oral output does not have any effect on vocabulary learning of impulsive Iranian EFL Learners.

H04: Written output does not have any effect on vocabulary learning of impulsive Iranian EFL Learners.

H5: In case of any effect, oral output has more effect than written output on vocabulary learning of reflective Iranian EFL learners.

H6: In case of any effect, Oral output has more effect than written output on vocabulary learning of impulsive Iranian EFL learners.

\section{Review of the Literature}

\subsection{Historical Overview}

The quest for findings effective vocabulary learning and teaching approaches dates back to 1960s (Wei, 2007). As this field of research grew attention among scholars, in the next 40 years, a considerable number of publications dealt with this issue (Nation, 2001). One of the very first attempts of scholars in this regard has been defining vocabulary learning. Indeed, knowing a word has been defined in more or less the same manner. As stated by Kersten (2010) there are two sides to knowing a words, i.e., form and meaning. Laufer and Girsai (2008) noted that the most significant component of word knowledge to master is the relationship between form and meaning. In addition, Nation (2001) emphasized the importance of learning word components such as spelling and pronunciation. Regardless of how knowing a word is interpreted, Schmitt and McCarthy (1997) contended that the approach adopted to learning vocabulary is of prime significance.

Research on effective vocabulary learning and teaching approaches is replete with contradictions. There have been conflicts among scholars relative to superiority of these methods. For example, Oxford and Acarcella (1994) believed that vocabulary learnt through de-contextualize teaching methods would be forgotten quickly, whereas Nielson (2006) stated that decontextualized methods are more suitable for low proficiency level learners, and incidental learning is more suitable for experienced learners.

Other scholars, especially under the influence of findings in cognitive psychology, designed myriad methods to teach vocabulary. A few of these methods, approaches and hypotheses include depth of processing hypothesis, The Key Word Method, The Sentence Writing Method and out-put-based vocabulary learning (Schmitt, 2008).

\subsection{Theoretical Overview}

One of the recent approach to vocabulary learning is Output-based vocabulary. It is an approach based on Swain's output hypothesis proposed in 1985. Contrary to Krashen's view (1985) which perpetuates the significant of input in learning, Swain's output hypothesis (1985), posits that production of language has a direct effect on acquisition of language by language learners which can occur by producing sentences and new vocabulary in an output process. Swain further explains that language learners' involvement in a meaningful context can increase their automaticity and learning through three functions (a) The noticing/Triggering function; (b) Hypothesis testing; (c) Metalinguistic function. Lee and VanPatten (2003) stated that output-based activities are communicative and form-focused. These activities, as stated by them, involve exchange of previous knowledge and access to structures to express meaning.

There are two main types of output, i.e., written and oral (Renvall, 2014). Contrary to oral and written input which defines how content should be received, oral and written output refer to how language is produced (Krashen, 1985). As the names suggest, written output refers to producing the language in the written from and oral output is production of language in the oral form. Lee and VanPatten (2003) stated that output, either oral or written, should be presented in a structured manner. Features of structured output in Lee and VanPatten (2003) definition of structured output were: (a) presenting things one by one, (b) meaning-focused activities, (c) connecting sentences, (d) using both modes of output, i.e., oral and written, (d) answering to the content of output collaboratively, (e) sufficient knowledge of from.

As stated by $\mathrm{Gu}$ (2013) vocabulary instruction is a multifaceted issue and has various dimensions. He further explained that one should consider 4 different issues to correctly deliver either input-based or output-based instruction, i.e., person, task, context, and strategy. He explained that "the strategies a learner uses and the effectiveness of these strategies very much depend on the learner him/herself (e.g., attitude, motivation, prior knowledge), the learning task at 
hand (e.g., type, complexity, difficulty, and generality), and the learning environment (e.g., the learning culture, the richness of input and output opportunities) (p.3).

Output-based approach to vocabulary learning is of two main types

Learning style is another variable in this study. James and Gardner (1995) stated that learning style is" the complex manner in which, and conditions under which, learners most effectively perceive, process, store, and recall what they are attempting to learn" (p.20). However, the term "learning style" is often used in literature to refer to learners' sensory preferences and cognitive styles. It is also used to refer to learners' personality types (Cassidy, 2004). Mortimore (2003) differentiated between learning styles and cognitive styles by explaining that while learning styles are stable, cognitive styles are less stable.

As stated earlier, personality, cognitive and sensory styles are three main components of learning styles (Dornyei, 2005). Oxford (2001) believed that extroverted versus introverted, random-intuitive versus concrete sequential, and closure-oriented versus open oriented are among personality learning styles, whereas visual, tactile/kinesthetic, and auditory styles are among sensory learning styles. Although Oxford (2001) and Dornyei (2005) considered a wide range of learning styles, impulsivity and reflectivity were not listed by them in their taxonomies. Other scholars such as Brown (2007) put emphasis on the impulsivity ad reflectivity. Brown (2007) states that an impulsive person "is a person who tends to make a quick or gambling guess at an answer to a problem and a reflective person tends to make a slower, more calculated decision"(p. 127). He also explains that a reflective person, on the other hand, tends to think before making decisions.

\subsection{Empirical Overview}

A number of studies have investigated the effect of output-based instruction and learning styles on vocabulary learning. A study was conducted by Izumi (1999) to find out if the output produced by the learners could affect noticing of the linguistic form in case input was subsequently provided. He concluded that the output produced by the learners could positively affect spelling and pronunciation of the words. Kitajima (2001) study on the Japanese language learners also proved that the output produced by language learners' can cause longer term retention of vocabulary learning by the learners. The study compared the effect on vocabulary through input and vocabulary through output on language learner retention of vocabulary items.

In addition, Yaqubi, Rayati, and Gorgi (2010) carried out a research with regard to output-based tasks and vocabulary learning through reading comprehension tasks. They concluded that output-based instruction can help increase EFL learners vocabulary knowledge through multiple-choice items, fill-in-the-gap items and writing essays with the target words. Moreover, Spoon and Schell (1998) carried out a study with regard to learners' learning styles. They aimed at finding out how matched and mismatched leaning styles can affect learners' achievement. They concluded that categorizing learners based on their learning styles can meaningfully affect learners' achievement.

Naimie et al. (2010) conducted a similar study to find out the effect of matching learners' learning style on their achievement. 300 participants in their study from Azad University were given Felder and Soloman's (1997) Learning Style Index (LSI). The participants were also surveyed and observed. They concluded that the main learning styles are active, sensing, visual, and global. They also concluded that matching learners' learning style can positively affect their achievements. Finally, the results of a study varied out by Tuan (2011) in Vietnam which focused on the extent of mismatch between learners' and teachers' style proved that the learners in the context of Vietnam were more visual, intuitive, active and sequential. They also observed that teachers; styles and learners' styles did not match.

\section{Method}

\subsection{Research Design}

This study was conducted as a between subject design. In addition, the study had a quasi-experimental design, as the participants were selected from only one language center in the context of Iran.

\subsection{Participants and Sampling Procedure}

Power Analysis was conducted to realize the required number of participants for this study. By considering moderate to large effect size, it was revealed that at least 22 participants is required for each group. Next, consenting participants $(\mathrm{n}=182)$ were distinguished from non-consenting participants $(\mathrm{n}=210)$ at Azarbayjan language institute in Tabriz, Iran. Multilevel sampling procedure was used in this study. In the first stage, Nelson vocabulary test was administered to the population and one hundred thirty-one $(\mathrm{N}=131)$ intermediate learners (considering 1SD above and below the mean score) were chosen as the participants for the study. In the next stage, the participants were given the "Questionnaire for Reflective Thinking" (QRT) (Kember et al., 2000), and Barratt et al. (1975) BIS 11 "Impulsiveness Questionnaire” to be homogenized based on their learning style as reflective or impulsive learners. Based on their impulsive and reflective learning styles, they were divided into 5 different groups for the study consisting of 2 experimental impulsive groups that went through oral and written output-based instruction, 2 experimental reflective groups that went through oral and written output-based instruction and a control group that went through input-based instruction. The age range of subjects was between 16 and 27, though age was not considered a factor in the study. 
As the target population for this study was Iranian EFL learners, it would have been more appropriate to test all participants in the Iranian context; however, the researchers did not have access to this population. Table 1 reveals the demographics of the participants.

Table 1. Participants’ Demographic Data

\begin{tabular}{llllcc}
\hline Group & $\mathrm{N}$ & First language & Proficiency level & Age & Gender \\
\hline Control & 32 & Azeri/Persian & Intermediate & Adult & Mixed \\
Impulsive Oral & 24 & Azeri/Persian & Intermediate & Adult & Mixed \\
Reflective Oral & 21 & Azeri/Persian & Intermediate & Adult & Mixed \\
Impulsive Written & 24 & Azeri/Persian & Intermediate & Adult & Mixed \\
Reflective Written & 22 & Azeri/Persian & Intermediate & Adult & Mixed \\
\hline
\end{tabular}

\subsection{Procedure}

Having selected the participants, the treatment phase of the study was conducted for 15 sessions over the period of 2 months. Lee and VanPatten (2003) concept of structured output-based tasks (as explained in the review of literature) was used to design the tasks.

In the oral groups, the target words accompanied with their dictionary meaning and synonyms were exposed to the participants. These words were both presented and practiced orally. This gave the participants the opportunity to both hear the pronunciation of the words and to practice them. Each mistake committed by the participants with regard to the pronunciation was rectified by the teacher or other peers in the class. The participants produced more sentences orally and negotiated their meaning with the peers and the teacher. The teacher attempted to ask as many questions as possible to push participants to produce sentences using the target words. As the focus in this group was on oral production of language, neither the participants nor the teacher produced the language in the written form.

Contrary to the oral output group, in the written output group, all activities were written. The teacher wrote every word with its definition on the board. The participants copied the words in their notebooks. Next, the teacher encouraged them to make sentences (examples) using the words. They were provided with feedback on their sentences when necessary. In case revisions were required by the participants, they were given adequate time to do so. They were given time to negotiate their sentences with other peers in the class. At the end of each session, all sentences written by the participants were corrected by the teacher.

The procedure in the control group was different from the experimental groups and more similar to conventional language classes. After clarifying the meaning of the words, the subjects were provided with examples through mechanical drills, whereas in the experimental groups, the teacher pushed subjects to produce examples, either written or oral, themselves. It means that, the focus of the exercises was shifted from the output produced by the subjects to mechanical drills conducted by the teacher. Yet, another significant difference between the control group and the experimental group was that in the treatment phase of the experimental groups, the teacher attempted not to intervene, give examples, write on the board, etc. It was mostly the duty of the subjects to produce oral samples in the oral outputbased class and written samples in the written output-based classes, albeit, a mixture of both was produced by the participants in the control group.

In the last phase of the study, the learners received the validated researcher-made vocabulary test as posttest. It included 30 multiple-choice items. The subjects were supposed to read the items, and then check the right words out of the four options. In order to make sure the vocabularies used in this test are as difficult as the ones used in the pretest, the researchers used the vocabulary in the pretest to design the posttest.

Needles to mention that the posttest was piloted before being administered to the participants. In the pilot study of the posttest, the researcher gauged the reliability and validity of the posttest. First, to estimate the content validity, the researcher submitted the test to two experts in the area. The experts were asked to modify or remove the probable problems. In order to gauge the reliability of the test, it was given to a group of learners $(\mathrm{N}=30)$ at the one level higher than the main participants. Item analysis is carried out to gauge the standardization of the test.

\section{Results and Discussion}

The one-way analysis of variances (one-way ANOVA) and independent t-test were run to probe the research questions posed in this study. Both One-way ANOVA and independent t-test have two main assumptions; homogeneity of variances which will be discussed below when presenting the results, and normality. As displayed in Table 2, the ratios of skewness and kurtosis over their standard errors were within +/- 1.96 (Stevens, 2009). Thus, it can be claimed that the present data enjoyed normal distribution. 
Table 2. Testing Normality Assumption

\begin{tabular}{lllllllll}
\hline \multirow{2}{*}{ Group } & & \multicolumn{3}{l}{ Skewness } & \multicolumn{5}{c}{ Kurtosis } \\
\cline { 2 - 9 } Control & Pretest & 32 & .291 & .414 & 0.70 & -1.212 & .809 & -1.50 \\
& Posttest & 32 & .007 & .414 & 0.02 & -.930 & .809 & -1.15 \\
\hline \multirow{2}{*}{ Oral output } & Pretest & 45 & .094 & .354 & 0.27 & -.727 & .695 & -1.05 \\
& Posttest & 45 & .112 & .354 & 0.32 & -.590 & .695 & -0.85 \\
\hline \multirow{2}{*}{ Written output } & Pretest & 46 & .043 & .350 & 0.12 & -.791 & .688 & -1.15 \\
& Posttest & 46 & -.214 & .350 & -0.61 & -.411 & .688 & -0.60 \\
\hline
\end{tabular}

\subsection{Pretest of Vocabulary}

A one-way analysis of variances was run to compare the oral, written and control groups' means on the pretest of grammar in order to prove that they enjoyed the same level of vocabulary knowledge prior to the main study. Before discussing the results, it should be mentioned that the assumption of homogeneity of variances was met (Levene's $\mathrm{F}$ ( 2 , $120)=2.15, \mathrm{P}=.120$ ) (Table 3 ).

Table 3. Levene's Test of Equality of Error Variances

\begin{tabular}{llll}
\hline E & df1 & df2 & Sig. \\
\hline 2.157 & 2 & 120 & .120 \\
\hline
\end{tabular}

As displayed in Table 4 the control $(\mathrm{D})(\mathrm{M}=17.66, \mathrm{SD}=1.40)$, oral output $(\mathrm{M}=18, \mathrm{SD}=1.17)$ and written output (M $=17.98, \mathrm{SD}=1.24)$ groups had almost the same means on the pretest of vocabulary.

Table 4. Descriptive Statistics, Pretest of Vocabulary by Groups

\begin{tabular}{|c|c|c|c|c|c|c|}
\hline & \multirow{3}{*}{$\mathrm{N}$} & \multirow{3}{*}{ Mean } & \multirow{3}{*}{ Std. Deviation } & \multirow{3}{*}{ Std. Error } & \multicolumn{2}{|c|}{$95 \%$ Confidence } \\
\hline & & & & & \multicolumn{2}{|c|}{ Interval for Mean } \\
\hline & & & & & Lower Bound & Upper Bound \\
\hline Control & 32 & 17.66 & 1.405 & .248 & 17.15 & 18.16 \\
\hline Oral output & 45 & 18.00 & 1.148 & .171 & 17.66 & 18.34 \\
\hline Written output & 46 & 17.98 & 1.220 & .180 & 17.62 & 18.34 \\
\hline Total & 123 & 17.90 & 1.244 & .112 & 17.68 & 18.12 \\
\hline
\end{tabular}

Based on the results displayed in Table $5,\left(\mathrm{~F}(2,120)=.848, \mathrm{P}=.431, \omega^{2}=.002\right.$ representing a weak effect size $)$ it can be concluded that there were not significant differences between the means of the three groups on the pretest of vocabulary. Thus it can be claimed that they were homogenous in terms of their vocabulary knowledge prior to the main study.

Table 5. One-way ANOVA, Pretest of Vocabulary by Groups

\begin{tabular}{llllll}
\hline & Sum of Squares & Df & Mean Square & F & Sig. \\
\hline Between groups & 2.632 & 2 & 1.316 & .848 & .431 \\
Within groups & 186.197 & 120 & 1.552 & & \\
Total & 188.829 & 122 & & & \\
\hline
\end{tabular}

\subsection{Posttest of Vocabulary}

A researcher-made test consisting of 30 items was made to be used as the posttest. The reliability of the test was gauged using Cronbach alpha index. 
Table 6. Reliability of the Posttest

\begin{tabular}{lcc}
\hline \multicolumn{2}{c}{ Cronbach's alpha } & N of Items \\
\hline Posttest & .881 & 30 \\
\hline
\end{tabular}

As can be seen in Table 6 , the posttest has sufficient reliability $(\alpha=.881)$. In addition, item facility (IF) and items discrimination (ID) was gauged for the posttest. The table below shows the item analysis of the test.

Table 7. Item Analysis Results

\begin{tabular}{llllll}
\hline Item & IF & ID & Item & IF & ID \\
\hline 1 & 0.63 & 0.47 & 16 & 0.57 & 0.33 \\
2 & 0.63 & 0.33 & 17 & 0.60 & 0.40 \\
3 & 0.53 & 0.53 & 18 & 0.60 & 0.40 \\
4 & 0.63 & 0.33 & 19 & 0.63 & 0.33 \\
5 & 0.60 & 0.53 & 20 & 0.67 & 0.53 \\
6 & 0.60 & 0.67 & 21 & 0.63 & 0.47 \\
7 & 0.63 & 0.47 & 22 & 0.60 & 0.40 \\
8 & 0.63 & 0.33 & 23 & 0.63 & 0.33 \\
9 & 0.60 & 0.40 & 24 & 0.63 & 0.47 \\
10 & 0.63 & 0.47 & 25 & 0.57 & 0.33 \\
11 & 0.60 & 0.53 & 26 & 0.67 & 0.40 \\
12 & 0.57 & 0.33 & 27 & 0.63 & 0.47 \\
13 & 0.63 & 0.47 & 28 & 0.63 & 0.47 \\
14 & 0.63 & 0.33 & 29 & 0.60 & 0.27 \\
15 & 0.63 & 0.47 & 30 & 0.63 & 0.47 \\
\hline
\end{tabular}

\subsection{Testing the Research Hypotheses}

\subsubsection{The First Research Hypothesis.}

H01: Oral output does not have any effect on vocabulary learning of Iranian reflective EFL learners.

An independent t-test was run to compare the oral output reflective and control groups' performance on the posttest of vocabulary in order to probe the first research question. Based on the results displayed in Table 8 , it can be claimed that the reflective oral output group $(\mathrm{M}=22.38, \mathrm{SD}=1.59)$ had a higher mean on the posttest of vocabulary than the control group $(\mathrm{M}=19.88, \mathrm{SD}=1.73)$.

Table 8. Descriptive Statistics; Posttest of Vocabulary by Groups (Reflective)

\begin{tabular}{llllll}
\hline & Group & N & Mean & Std. Deviation & Std. Error Mean \\
\hline Posttest & Oral output & 21 & 22.38 & 1.596 & .348 \\
Vocab & Control & 32 & 19.88 & 1.737 & .307 \\
\hline
\end{tabular}

The results of the independent t-test $(\mathrm{t}(51)=5.30, \mathrm{p}=.000, \mathrm{r}=.596$ representing a large effect size) (Table 9) indicate that the reflective oral output group had significantly outperformed the control group on the posttest of vocabulary. Thus the first null-hypothesis was rejected.

Table 9. Independent Samples Test, Posttest of Vocabulary by Groups (Reflective)

\begin{tabular}{|c|c|c|c|c|c|c|c|c|}
\hline \multicolumn{4}{|c|}{ Levene's test } & \multicolumn{5}{|c|}{ T-test for equality of means } \\
\hline \multirow{2}{*}{$\mathrm{F}$} & \multirow[t]{2}{*}{ Sig. } & \multirow[t]{2}{*}{$\mathrm{T}$} & \multirow[t]{2}{*}{ Df } & \multirow{2}{*}{$\begin{array}{l}\text { Sig. (2- } \\
\text { tailed) }\end{array}$} & \multirow{2}{*}{$\begin{array}{c}\text { Mean } \\
\text { difference }\end{array}$} & \multirow{2}{*}{$\begin{array}{l}\text { Std. error } \\
\text { difference }\end{array}$} & \multicolumn{2}{|c|}{$\begin{array}{l}\text { 95\% Confidence interval of the } \\
\text { difference }\end{array}$} \\
\hline & & & & & & & Lower & Upper \\
\hline .771 & .384 & 5.302 & 51 & .000 & 2.506 & .473 & 1.557 & 3.455 \\
\hline
\end{tabular}




\subsubsection{The Second Research Hypothesis}

H02: Written output does not have any effect on vocabulary learning of reflective Iranian EFL Learners.

An independent t-test was run to compare the written output reflective and control groups' performance on the posttest of vocabulary in order to probe the second research question. Based on the results displayed in Table 10, it can be claimed that the reflective written output group $(\mathrm{M}=23.23, \mathrm{SD}=1.47)$ had a higher mean on the posttest of vocabulary than the control group $(\mathrm{M}=19.88, \mathrm{SD}=1.73)$.

Table 10. Descriptive Statistics; Posttest of Vocabulary by Groups (Reflective)

\begin{tabular}{llllll}
\hline & Group & N & Mean & Std. Deviation & Std. Error mean \\
\hline Posttest & Written Output & 22 & 23.23 & 1.478 & .315 \\
Vocab & Control & 32 & 19.88 & 1.737 & .307 \\
\hline
\end{tabular}

The results of the independent t-test $(\mathrm{t}(52)=7.39, \mathrm{p}=.000, \mathrm{r}=.716$ representing a large effect size) (Table 11) indicate that the reflective written output group had a significantly outperformed the control group on the posttest of vocabulary. Thus the second null-hypothesis was rejected.

Table 11. Independent Samples Test, Posttest of Vocabulary by Groups (Reflective)

\begin{tabular}{|c|c|c|c|c|c|c|c|c|}
\hline \multicolumn{4}{|c|}{ Levene's test } & \multicolumn{5}{|c|}{ T-test for equality of means } \\
\hline \multirow[t]{2}{*}{$\mathrm{F}$} & \multirow[t]{2}{*}{ Sig. } & \multirow[t]{2}{*}{$\mathrm{T}$} & \multirow[t]{2}{*}{ Df } & \multirow{2}{*}{$\begin{array}{l}\text { Sig. (2- } \\
\text { tailed) }\end{array}$} & \multirow{2}{*}{$\begin{array}{c}\text { Mean } \\
\text { difference }\end{array}$} & \multirow{2}{*}{$\begin{array}{l}\text { Std. error } \\
\text { difference }\end{array}$} & \multicolumn{2}{|c|}{$\begin{array}{l}\text { 95\% Confidence interval of the } \\
\text { difference }\end{array}$} \\
\hline & & & & & & & Lower & Upper \\
\hline 1.036 & .313 & 7.394 & 52 & .000 & 3.352 & .453 & 2.442 & 4.262 \\
\hline
\end{tabular}

\subsubsection{The Third Research Hypothesis}

H03: Oral output does not have any effect on vocabulary learning of impulsive Iranian EFL Learners.

An independent t-test was run to compare the oral output impulsive and control groups' performance on the posttest of vocabulary in order to probe the third research question. Based on the results displayed in Table 12 it can be claimed that the impulsive oral output group $(\mathrm{M}=21.04, \mathrm{SD}=1.30)$ had a higher mean on the posttest of vocabulary than the control group $(\mathrm{M}=19.88, \mathrm{SD}=1.73)$.

Table 12. Descriptive Statistics; Posttest of Vocabulary by Groups (Impulsive)

\begin{tabular}{llllll}
\hline & Group & N & Mean & Std. Deviation & Std. Error Mean \\
\hline Posttest & Oral output & 24 & 21.04 & 1.301 & .266 \\
Vocab & Control & 32 & 19.88 & 1.737 & .307 \\
\hline
\end{tabular}

The results of the independent $\mathrm{t}$-test $(\mathrm{t}(54)=2.75, \mathrm{p}=.008, \mathrm{r}=.350$ representing a moderate effect size) (Table 13) indicated that the impulsive oral output group had a moderately outperformed the control group on the posttest of vocabulary. Thus the third null-hypothesis was rejected, although the results should be interpreted cautiously due to the moderate effect size value of .350 .

Table 13. Independent Samples Test, Posttest of Vocabulary by Groups (Impulsive)

\begin{tabular}{|c|c|c|c|c|c|c|c|c|}
\hline Leven & 's test & & & & T-test $\mathrm{f}$ & equality of & eans & \\
\hline $\mathrm{F}$ & Sig. & $\mathrm{T}$ & Df & Sig. (2- & Mean & Std. error & $95 \%$ & of the \\
\hline & & & & & & & Lower & Upper \\
\hline 3.108 & .084 & 2.759 & 54 & .008 & 1.167 & 423 & .319 & 2.015 \\
\hline
\end{tabular}




\subsubsection{The Fourth Research Hypothesis}

H04: Written output does not have any effect on vocabulary learning of impulsive Iranian EFL Learners?

An independent t-test was run to compare the written output impulsive and control groups' performance on the posttest of vocabulary in order to probe the fourth research question. Based on the results displayed in Table 14, it can be claimed that the impulsive written output group $(\mathrm{M}=21.75, \mathrm{SD}=1.56)$ had a higher mean on the posttest of vocabulary than the control group $(\mathrm{M}=19.88, \mathrm{SD}=1.73)$.

Table 14. Descriptive Statistics; Posttest of Vocabulary by Groups (Impulsive)

\begin{tabular}{llllll}
\hline & Group & N & Mean & Std. Deviation & Std. Error Mean \\
\hline Posttest & Written Output & 24 & 21.75 & 1.567 & .320 \\
Vocab & Control & 32 & 19.88 & 1.737 & .307 \\
\hline
\end{tabular}

The results of the independent t-test $(\mathrm{t}(54)=4.16, \mathrm{p}=.000, \mathrm{r}=.493$ representing an almost large effect size) (Table 15) indicate that the impulsive written output group had a significantly outperformed the control group on the posttest of vocabulary. Thus the fourth null-hypothesis was rejected.

Table 15. Independent Samples Test, Posttest of Vocabulary by Groups (Impulsive)

\begin{tabular}{|c|c|c|c|c|c|c|c|c|}
\hline \multicolumn{4}{|c|}{ Levene's test } & \multicolumn{5}{|c|}{ T-test for equality of means } \\
\hline \multirow[t]{2}{*}{$\mathrm{F}$} & \multirow[t]{2}{*}{ Sig. } & \multirow[t]{2}{*}{$\mathrm{T}$} & \multirow[t]{2}{*}{ Df } & \multirow{2}{*}{$\begin{array}{l}\text { Sig. (2- } \\
\text { tailed) }\end{array}$} & \multirow{2}{*}{$\begin{array}{c}\text { Mean } \\
\text { difference }\end{array}$} & \multirow{2}{*}{$\begin{array}{l}\text { Std. error } \\
\text { difference }\end{array}$} & \multicolumn{2}{|c|}{$\begin{array}{l}\text { 95\% Confidence interval of the } \\
\text { difference }\end{array}$} \\
\hline & & & & & & & Lower & Upper \\
\hline .936 & .338 & 4.166 & 54 & .000 & 1.875 & .450 & .973 & 2.777 \\
\hline
\end{tabular}

\subsubsection{The Fifth Research Hypothesis}

H5: In case of any effect, oral output has more effect than written output on vocabulary learning of reflective Iranian EFL learners?

An independent t-test was run to compare the oral and written output reflective groups' performance on the posttest of vocabulary in order to probe the fifth research question. Based on the results displayed in Table 16, it can be claimed that the reflective written output group $(\mathrm{M}=23.23, \mathrm{SD}=1.47)$ had a higher mean on the posttest of vocabulary than the reflective oral output group $(\mathrm{M}=22.38, \mathrm{SD}=1.59)$.

Table 16. Descriptive Statistics; Posttest of Vocabulary by Groups (Reflective)

\begin{tabular}{llllll}
\hline & Group & N & Mean & Std. Deviation & Std. Error Mean \\
\hline Posttest & Written output & 22 & 23.23 & 1.478 & .315 \\
Vocab & Oral output & 21 & 22.38 & 1.596 & .348 \\
\hline
\end{tabular}

The results of the independent t-test $(\mathrm{t}(41)=1.80, \mathrm{p}=.087, \mathrm{r}=.270$ representing a weak to moderate effect size) (Table 17) indicated that there was not any significant difference between the reflective oral and written output groups' means on the posttest of vocabulary. Thus the fifth null-hypothesis was supported.

Table 17. Independent Samples Test, Posttest of Vocabulary by Groups (Reflective)

\begin{tabular}{|c|c|c|c|c|c|c|c|c|}
\hline \multicolumn{4}{|c|}{ Levene's test } & \multicolumn{5}{|c|}{ T-test for equality of means } \\
\hline \multirow{2}{*}{$\mathrm{F}$} & \multirow{2}{*}{ Sig. } & \multirow{2}{*}{$\mathrm{T}$} & \multirow{2}{*}{ Df } & \multirow{2}{*}{$\begin{array}{l}\text { Sig. (2- } \\
\text { tailed) }\end{array}$} & \multirow{2}{*}{$\begin{array}{c}\text { Mean } \\
\text { difference }\end{array}$} & \multirow{2}{*}{$\begin{array}{l}\text { Std. error } \\
\text { difference }\end{array}$} & \multicolumn{2}{|c|}{$\begin{array}{l}95 \% \text { Confidence interval of the } \\
\text { difference }\end{array}$} \\
\hline & & & & & & & Lower & Upper \\
\hline .002 & .962 & 1.805 & 41 & .078 & .846 & 469 & -.100 & 1.793 \\
\hline
\end{tabular}

The negative $95 \%$ lower confidence interval of -.10 (Table 17) indicted that the difference between the two groups' means can be zero. Thus the above mentioned conclusion as no significant difference between the reflective oral and written output groups' means on the posttest of vocabulary was correctly made. 
4.3.6 The Sixth Research Question

H6: In case of any effect, Oral output has more effect than written output on vocabulary learning of impulsive Iranian EFL learners.

An independent t-test was run to compare the oral and written output impulsive groups' performance on the posttest of vocabulary in order to probe the fifth research question. Based on the results displayed in Table 18, it can be claimed that the impulsive written output group $(\mathrm{M}=21.75, \mathrm{SD}=1.56)$ had a higher mean on the posttest of vocabulary than the impulsive oral output group $(\mathrm{M}=21.04, \mathrm{SD}=1.30)$.

Table 18. Descriptive Statistics; Posttest of Vocabulary by Groups (Impulsive)

\begin{tabular}{llllll}
\hline & Group & N & Mean & Std. Deviation & Std. Error Mean \\
\hline Posttest & Written output & 24 & 21.75 & 1.567 & .320 \\
Vocab & Oral output & 24 & 21.04 & 1.301 & .266 \\
\hline
\end{tabular}

The results of the independent $\mathrm{t}$-test $(\mathrm{t}(46)=1.70, \mathrm{p}=.095, \mathrm{r}=.243$ representing a weak to moderate effect size) (Table 19) indicated that there was not any significant difference between the impulsive oral and written output groups' means on the posttest of vocabulary. Thus the sixth null-hypothesis was supported.

Table 19. Independent Samples Test, Posttest of Vocabulary by Groups (Impulsive)

\begin{tabular}{|c|c|c|c|c|c|c|c|c|}
\hline \multicolumn{4}{|c|}{ Levene's test } & \multicolumn{5}{|c|}{ T-test for equality of means } \\
\hline \multirow[t]{2}{*}{$\mathrm{F}$} & \multirow[t]{2}{*}{ Sig. } & \multirow[t]{2}{*}{$\mathrm{T}$} & \multirow[t]{2}{*}{ Df } & \multirow{2}{*}{$\begin{array}{l}\text { Sig. }(2- \\
\text { tailed) }\end{array}$} & \multirow{2}{*}{$\begin{array}{c}\text { Mean } \\
\text { difference }\end{array}$} & \multirow{2}{*}{$\begin{array}{l}\text { Std. error } \\
\text { difference }\end{array}$} & \multicolumn{2}{|c|}{$\begin{array}{l}\text { 95\% Confidence interval of the } \\
\text { difference }\end{array}$} \\
\hline & & & & & & & Lower & Upper \\
\hline .398 & .531 & 1.703 & 46 & .095 & .708 & .416 & -.129 & 1.545 \\
\hline
\end{tabular}

The negative $95 \%$ lower confidence interval of -.12 (Table 19) indicted that the difference between the two groups' means can be zero. Thus the above mentioned conclusion as no significant difference between the impulsive oral and written output groups' means on the posttest of vocabulary was correctly made.

\section{Discussion}

It can be claimed that the findings of this study are in line with the findings of the study carried out by Izumi (1999): Output produced by the learners through making sentences could help learners learn new words, especially in terms of word meaning and spelling. The main focus of the current study, as well, was on vocabulary learning. As it was observed that both oral and written output instruction had a significant positive effect on vocabulary learning of Iranian impulsive and reflective learners. Not only are the findings of the current study in line with the findings of Izumi (1999), but also this study delved into the learning styles of the learners.

The findings of this study are also congruent with the findings of Hadley (2003): Most scholars believe that individual differences between the learners can affect the rate and degree of their success. Distinguishing learners into impulsive and reflective learning styles in this study could affect vocabulary acquisition among the learners, as the learners in the experimental groups outperformed those in the control group.

Hulstijn and Laufer (2001) carried out an experiment which contained three tasks; namely, a reading task with marginal glosses, a comprehension task through filling in the gaps and a writing task with target words. The third task, i.e., writing composition proved to be the most effective of the three in the context of the involvement load hypothesis as it had an emphasis on written output. The written task gives the learners the opportunity to analyze their work and use their own cognition to learn. That is why it is stated that according to Involvement Load Hypothesis, the more the learners get involved in a task, the higher their chance of learning-especially in terms of vocabulary learning. The focus of the current study was on the learners' production as the main tool for learning. Thus, the learners were involved in written and oral tasks and were supposed to use their cognition to solve the tasks. It can explain why vocabulary learning through output instruction in more effective than input-based instruction.

In addition, Yaqubi, Rayati, and Gorgi (2010) posited that various types of exercises can be added to reading texts to form reading tasks, e.g., multiple-choice items, filling in the gaps or writing tasks. However, the most effective type of task is the one which is output-oriented. This study also proved that output-oriented tasks have significant effect on vocabulary learning. It is also proved that tasks given to learners such as oral or written production of sentences with newly encountered words can affect learning vocabulary among intermediate EFL learners. 


\section{Conclusion}

The findings of this study proved that considering the thinking style of the learners (i.e. impulsivity and reflectivity in this particular study) and oral and written output instruction can significantly affect the outcome of the courses as it was proved that Iranian impulsive and reflective learners benefit from both oral output instruction and written output instruction, though the effect of oral output instruction and written output instruction was no meaningfully different on impulsive and reflective learners.

\subsection{Pedagogical Implications of the Study}

Output-oriented teaching and learning procedures, as observed to be effective, could be used as an alternative in education to enhance learners' understanding and practice opportunities. In addition, language teachers could consider the findings of the current study by adopting more recent types of instruction (i.e. output-based instruction) in situations where input-based teaching fails. Teachers can also use output-based approach if they intend to move from languagebased and learning-based approaches in teaching to learner-based ones. In addition, since students are supposed to learn via their own production by making verbal or non-verbal sentences, they receive more practice opportunities which can, in turn, raise their self-confidence level and reduce the stressful authority of the teacher in the classroom.

Therefore, in every level of education, the findings offer a wealth of opportunities to English teachers in these places to employ oral output and written output to enrich their instruction in order to motivate learners with these personality traits to expand their English vocabulary knowledge. In fact, English teachers may use the findings of the present study to train their students better and help them gain more fruitful results in the EFL vocabulary learning classes.

Moreover, identifying such findings will help individual learners to benefit from these instructions in the class and out of class time as their self-study to increase their vocabulary knowledge and, as a result; sooner reach their terminal goal, learning the foreign language, more effectively.

Furthermore, the prime suggestion of this study would be directed to educational systems. It comes highly recommended by the researcher that educational systems consider learners' different learning styles and try to distinguish them based on their learning styles to get the most out of the language courses.

\section{References}

Barratt, E. S., Patton, J., \& Stanford, M. (1975). Barratt Impulsiveness Scale. Barratt-Psychiatry Medical Branch, University of Texas.

Brown, H. D. (2007). Principles of language learning and teaching (5 $5^{\text {th }}$ ed.). New York: Pearson Education.

Cassidy, S. (2004). Learning styles: An overview of theories, models, and measures. Educational Psychology, 24(4), 419-441.

Coady, J., \& Huckin, T. (1997). Second language vocabulary acquisition. London: Cambridge University Press.

Dornyei, Z. (2005). The psychology of the language learner: Individual differences in second language acquisition. Mahwah, NJ: Lawrence Erlbaum. Associates, Publishers.

Felder, R. M., \& Soloman, B. A. (1997). Index of learning styles questionnaire. Retrieved on October, 14, 2015 from www.engr.ncsu.edu/learningstyles/ilsweb.html

Folse, K. S. (2008). Six vocabulary activities for the English language classroom. English Teaching Forum, $46(3), 12$.

Gu, P. Y. (2003). Vocabulary learning in a second language: Person, task, context and strategies. TESL-EJ, 7(2), 1-25.

Hadley, A. O. (2003). Teaching language in context ( $3^{\text {rd }}$ ed.).Massachusetts: Heinle \& Heinle.

Han, J. (2004). The effects of using and authoring web-based vocabulary tasks on Korean EFL learners' vocabulary acquisition. Foreign Languages Education, 11, 183-206.

Hawkar, A. A. (2014). Learning styles and their relation to teaching styles. International Journal of Language and Linguistics. 2(3), 241-245. doi: 10.11648/j.ijl1.20140203.23

Hulstijn, J. H., \& Laufer, B. (2001). Some empirical evidence for the involvement load hypothesis in vocabulary acquisition. Language Learning, 51, 539-558. doi: 10.1111/0023-8333.00164

Isazadeh, P., Makui, S. M. Z., \& Ansarian, L. (2016). Effect of Instructional vs. Authentic Video Materials on Introvert and Extrovert Iranian EFL Learners' Vocabulary Learning. International Journal of Education and Literacy Studies, 4(4), 1-10.

Izumi, S. (1999). Testing the output hypothesis. Studies in Second Language Acquisition, 21, 421-452.

James, W. B., \& Gardner, D. L. (1995). Learning styles: Implications for distance learning. New Directions for Adult and Continuing Education.67, 19-32.

Kember, D., Leung, D.Y. P., Jones, A., Loke, A. Y., McKey, J., Sinclair, Tse, H.,.., Yeung, E. (2000). Development of a Questionnaire to Measure the Level of Reflective Thinking (Azmonyar Poya. trans.). Assessment and Evaluation in Higher Education, 25(4). 
Kersten, S (2010). The mental lexicon and vocabulary learning. Tübingen: Verlag Narr

Kolb, A. Y., \& Kolb, D. A. (2005). Learning styles and learning spaces: Enhancing experiential learning in higher education. Academy of management learning \& education, 4(2), 193-212.

Krashen S.D. (1985). Input-based hypothesis: Issues and implications. U.K.: Longman

Kumaravadivelu, B. (2006). TESOL methods: Changing tracks, challenging trends. TESOL Quarterly, 40(1), 59-81.

Kitajima, R. (2001). The effect of instructional conditions on students' vocabulary retention. Foreign Language Annals, 34, 470-482. doi: 10.1111/j.1944-9720.2001.tb02086.x

Laufer, B. (1998). The development of passive and active vocabulary in a second language: Same or different? Applied linguistics, 19(2), 255-271.

Laufer, B, \& Girsai, N. (2008). Form-focused instruction in second language vocabulary learning: A case for contrastive analysis and translation. Applied Linguistics 29(4), 694-716.

Lee, J. F., \& Vanpatten, B. (2003). Making communicative language teaching happen. New York: McGraw Hill

Maftoon, P., \& Sharif Haratmeh, M. (2013). Effects of input and output-oriented tasks with different involvement loads on the receptive vocabulary knowledge of Iranian EFL learners. Research in Applied Linguistics, 1(1), 24-38.

Mortimore, T. (2003). Dyslexia and Learning Style. A Practitioner's Handbook. London: Whurr Publishers Ltd.

Naimie, Z., Siraj, S., Shagholi, R., \& Abuzaid, R. A. (2010). Did you cook your lesson based on right recipe? (Accommodating the Students Preferences in Class) Social Behavioral Sciences, 2, 383-387.

Nation, I.S. P. (2001). Learning vocabulary in another language. Cambridge, U.K: Cambridge University Press.

Oxford, R. L. (2001). Language learning styles and strategies. In. M. Celce-Murcia, Ed.Teaching English as a second or foreign language ( $3^{\text {rd }}$ ed.). USA: Heinle \& Heinle.

Oxford, R.L., \& Acarcella, R.C. (1994). Second language vocabulary learning among adults: State of the art in vocabulary instruction. System, 22(2), 231-243.

Oxford, R., \& Crookall, D. (1989). Research on language learning strategies: Methods, findings, and instructional issues. The Modern Language Journal, 73(4), 404-419.

Schmitt, N. (2008). Review article: Instructed second language vocabulary learning. Language teaching research, 12(3), 329-363.

Schmitt, N., \& McCarthy, M. (1997). Vocabulary: Description, acquisition and pedagogy. Cambridge: Cambridge University Press.

Spoon, J. C, \& Schell, J .W. (1998). Aligning student learning styles with instructor teaching. Journal of Industrial Teacher Education, 35(2), 41-56.

Stevens, J.P. (2009). Applied Multivariate Statistics for Social Sciences. (5 $5^{\text {th }}$ ed.). NY: Routledge.

Tuan, L. T. (2011). Matching and stretching learners' learning styles. Journal of Language Teaching and Research, 2(2), 285-294.

Yaqubi, B., Rayati, R.A., \& Gorgi, A. (2010). The involvement load hypothesis and vocabulary learning: The effect of task types and involvement index on L2 vocabulary acquisition. The Journal of Teaching Language Skills 1(1), 146163.

Yeh, Y., \& Wang, C. W. (2003). Effects of multimedia vocabulary annotations and learning styles on vocabulary learning. Calico Journal, 131-144.

Wei, M. (2007). An Examination of Vocabulary Learning of College-level Learners of English in China. Asian EFL J., 9(2), 93-114.

Winke, P. M., \& Abbuhl, R. (2007). Taking a closer look at vocabulary learning strategies: A case study of a Chinese foreign language class.Foreign Language Annals, 40(4), 697. 